\title{
STUDY OF MECHANICAL AND WEAR PROPERTIES OF EPOXY AND CARBON POWDER COMPOSITES WITH OR WITHOUT REINFORCEMENT (E-GLASS)
}

\author{
Lokesh V \\ Dept of Mechanical Engg \\ SIT, valachil, Mangaluru
}

\author{
Dr. Basava T \\ Head R\&D/IEDC \\ SDMIT, Ujire
}

\author{
Naveen C R \\ Dept of Mechanical Engg \\ SIT, valachil, Mangaluru
}

\begin{abstract}
An experimental investigation has been conducted to evaluate the mechanical properties and wear behavior of epoxy composite with different proportions of carbon powder without e glass as reinforcement as a first part of investigation. As a second part of investigation e glass-fiber reinforced in epoxy matrix filled with different proportions of carbon powder were developed.
\end{abstract}

Keywords- Composite, FRP, E-Glass Fibre, hardness, Dshore, wear test

\section{INTRODUCTION}

Materials with better properties have high demand to replace existing materials or to meet new requirements. The performance of continuous fiber reinforced polymer matrix composites is well known and adopted. The disadvantages of composites related to matrix dominated properties which limit their wide application and creates the need to develop new generation of composite materials. The adding of filler materials [1-6] to a polymer is a common thing. This improves mechanical and thermal properties, and also reduces the processing cost significantly. More than $50 \%$ of all polymers produced are in one or another filled [6] (2011) with inorganic fillers to achieve the desirable properties. Epoxy is used in industries in for coatings, electronics and aerospace applications. Epoxy is the dominant matrix material for light weight polymer- matrix structural composites such as carbon fiber composites.

\section{METHODOLOGY}

Hand layup technique is used for preparing epoxy/e glass/graphite hybrid composite material. Hand lay-up it is the simplest technique used for composite processing. The infrastructural requirement for this method is also minimal as the processing steps are simple.

The wax is pasted on surface of the mold to avoid the sticking problems. Required amount of E-glass fiber and epoxy is taken three times the weight of e-glass. E-glass are made in the form of chopped strand mats and placed at the surface of mold after pasting wax.

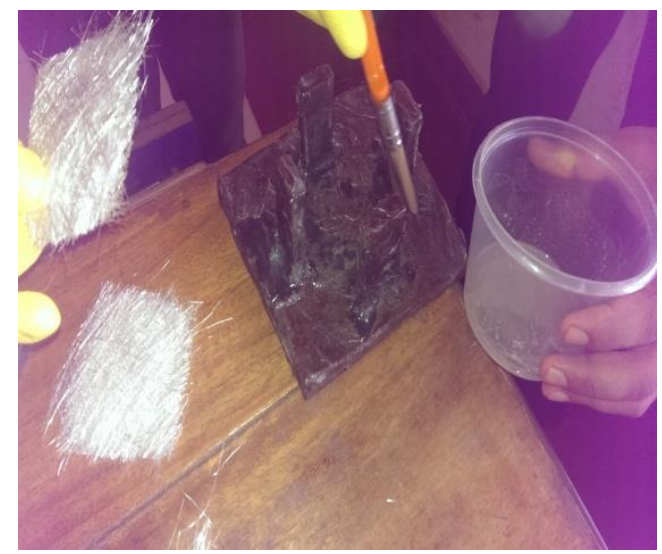

Fig: 1 Quenching with epoxy

Then the general purpose resin (epoxy) is mixed thoroughly with a Hardener hy951 of some \% of epoxy) and poured on the surface of layer which is placed already in the mold. The polymer is quenched by using brush and then spread all over the surface uniformly. [17] (2017). Since there is chance of formation of air cavities it is important to quench properly. Then the second layer of mat is placed on the polymer surface and again quenched on the mat-polymer layer So that if any air trapped can be removed. The process is repeated, till the required layers are prepared. After completing this much work, wax is pasted on the inner surface of the top mold plate which is then kept on the stacked layers and the pressure is applied. After curing either at room temperature, mold is opened after six to seven hours and the developed composite part is taken out and further processed. The time of curing depends on type of polymer used for composite processing. This method is mainly suitable for thermosetting polymer based composites. The investment is less compared to other methods The problem in the process is very slow. 
International Journal of Engineering Applied Sciences and Technology, 2020

Vol. 5, Issue 4, ISSN No. 2455-2143, Pages 415-419

Published Online August 2020 in IJEAST (http://www.ijeast.com)

\section{RESULTS AND DISCUSSION}

\subsection{Epoxy-Carbon composite material (without E-glass reinforcement)}

Table 3.1 Composition of the specimen

\begin{tabular}{|l|l|}
\hline Composite & Composition \\
\hline Plain & Epoxy (90\%)+Hardener (10\%) \\
\hline $\begin{array}{l}10 \% \\
\text { carbon }\end{array}$ & $\begin{array}{l}\text { Epoxy (80\%)+Hardener } \\
(10 \%)+C a r b o n(10 \%)\end{array}$ \\
\hline $\begin{array}{l}20 \% \\
\text { carbon }\end{array}$ & $\begin{array}{l}\text { Epoxy (70\%)+Hardener (10\%) } \\
+ \text { Carbon(20\%) }\end{array}$ \\
\hline $\begin{array}{l}30 \% \\
\text { carbon }\end{array}$ & $\begin{array}{l}\text { Epoxy (60\%)+Hardener (10\%)+ } \\
\text { Carbon(30\%) }\end{array}$ \\
\hline
\end{tabular}

\subsubsection{Mechanical Properties}

\subsubsection{Hardness test}

Table 3.2 Hardness number

\begin{tabular}{|c|c|c|c|c|}
\hline Composites & $\begin{array}{c}\text { Trial } \\
\mathbf{1}\end{array}$ & $\begin{array}{c}\text { Trial } \\
\mathbf{2}\end{array}$ & $\begin{array}{c}\text { Trial } \\
\mathbf{3}\end{array}$ & Avg \\
\hline Plain & 47 & 49 & 46 & 47 \\
\hline $10 \%$ Carbon & 47 & 50 & 53 & 50 \\
\hline $20 \%$ Carbon & 58 & 56 & 59 & 58 \\
\hline $30 \%$ Carbon & 67 & 70 & 67 & 68 \\
\hline
\end{tabular}

The higher hardness is exhibited by the $30 \mathrm{wt} \%$ carbon filled composite compared to other composition. The increase in carbon content results in an increase in brittleness of the composite.

\subsubsection{Compression Test}

It can be noticed that for the plain Epoxy material the compressive strength value along the specimen is 65.87 $\mathrm{N} / \mathrm{mm}^{2}$. With the addition of carbon as filler material it is seen that the compressive strength values are increasing. A maximum is seen at $30 \%$ carbon filled material.

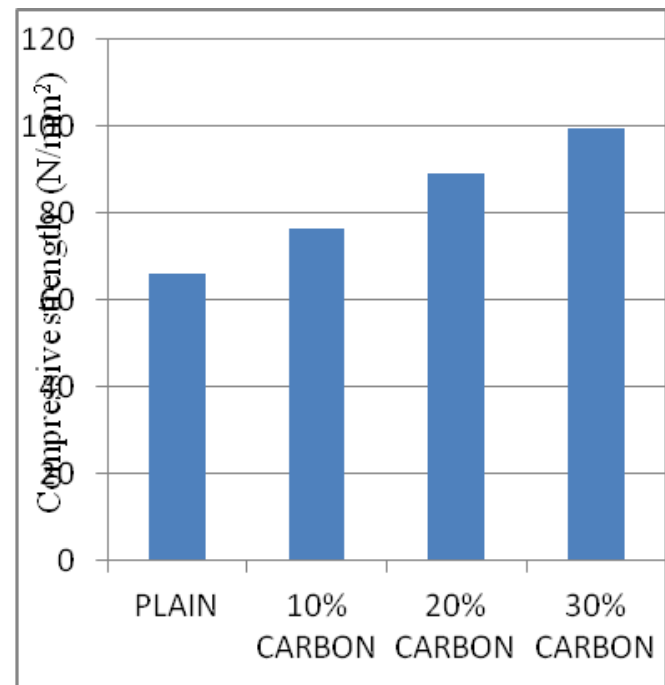

Fig. 2 Variation of compressive strength for different carbon \%

It can be noticed that for the plain Epoxy material the compressive strength value along the specimen is 65.87 $\mathrm{N} / \mathrm{mm}^{2}$. With the addition of carbon as filler material it is seen that the compressive strength values are increasing. A maximum is seen at $30 \%$ carbon filled material. For $30 \%$ carbon filled material the compressive strength was seen to be $99.26 \mathrm{~N} / \mathrm{mm}^{2}$. Compressive strength increases with increase in filler material because of increased grain content and strong bonding of the particles of carbon.

\subsubsection{Wear Test}

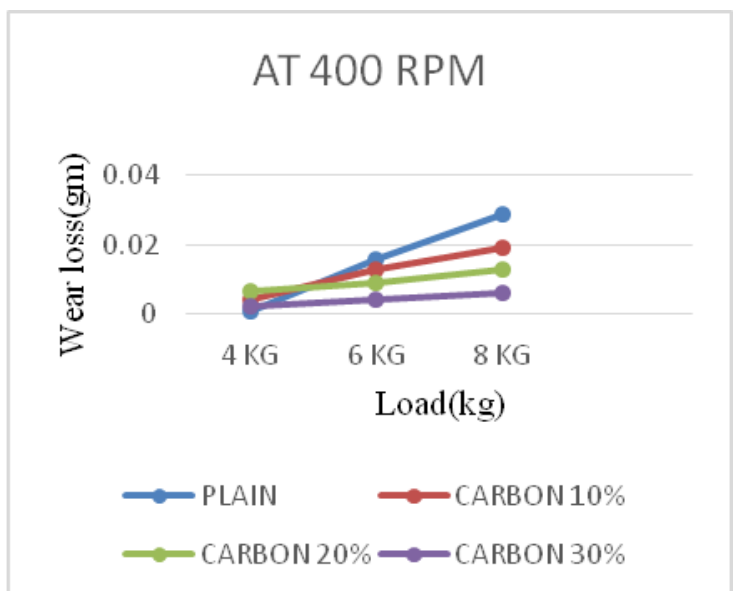

Fig 3. Wear loss at $400 \mathrm{rpm}$ at different load

The fig 3 shows the plot of wear loss and material compositions for $4 \mathrm{~kg}$ and $8 \mathrm{~kg}$ loads and under $400 \mathrm{rpm}$. From the graph it can be see that the plain composition specimen exhibited more material loss at $8 \mathrm{~kg}$ and the $30 \%$ carbon showed less wear loss. And at $4 \mathrm{~kg}$ the plain composition had 
less wear loss due to the factors like the friction and temperature at the contact surface which will be less for the plain specimen. The composite which is filled with $30 \mathrm{wt} \%$ exhibits less wear loss compared to other composites.

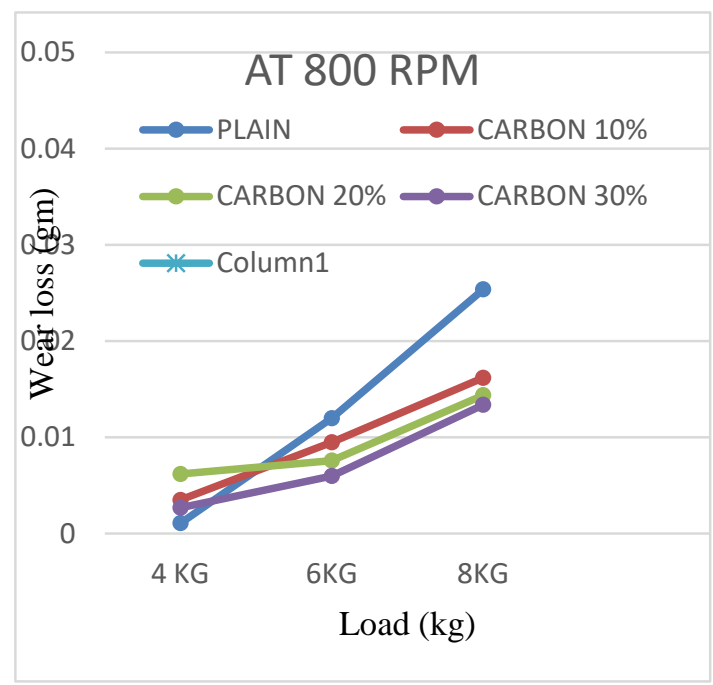

Fig 4 Wear loss at $800 \mathrm{rpm}$ at different load

The fig. 4 shows that carbon filled Epoxy composite exhibits lower wear volume loss than plain Epoxy composite. Moreover, the weight loss of the composites filled with natural fillers depends upon some basic characteristics such as, shape of the filler, size of the filler, and hardness and thermal conductivity of the filler materials.

\subsection{E glass-Epoxy-Carbon composite material (With Reinforcement)}

Table 3.3 Composition of the specimen

\begin{tabular}{|c|c|}
\hline Composites & Compositions \\
\hline Plain & $\begin{array}{l}\text { Epoxy }(65 w t \%)+\text { glass fiber } \\
(25 w t \%)+ \\
\text { Hardener }(10 w t \%)\end{array}$ \\
\hline $\begin{array}{l}\text { Carbon } \\
10 \mathrm{wt} \%\end{array}$ & $\begin{array}{l}\text { Epoxy }(55 \mathrm{wt} \%)+\text { glass fiber } \\
(25 \mathrm{wt} \%)+ \\
\text { Hardener }(10 \mathrm{wt} \%)+\text { carbon } \\
\text { powder }(10 \mathrm{wt} \%)\end{array}$ \\
\hline $\begin{array}{l}\text { Carbon } \\
20 \mathrm{wt} \%\end{array}$ & $\begin{array}{l}\text { Epoxy }(45 \mathrm{wt} \%)+\text { glass fiber } \\
(25 \mathrm{wt} \%)+ \\
\text { Hardner }(10 \mathrm{wt} \%)+\text { carbon } \\
\text { powder }(20 \mathrm{wt} \%)\end{array}$ \\
\hline $\begin{array}{l}\text { Carbon } \\
30 \mathrm{wt} \%\end{array}$ & $\begin{array}{l}\text { Epoxy }(35 \mathrm{wt} \%)+\text { glass fiber } \\
(25 \mathrm{wt} \%)+ \\
\text { Hardner }(10 \mathrm{wt} \%)+\text { carbon } \\
\text { powder }(10 \mathrm{wt} \%)\end{array}$ \\
\hline
\end{tabular}

\subsubsection{Mechanical Properties}

\subsubsection{Hardness test}

Table 3.4 Hardness number

\begin{tabular}{|c|l|l|l|l|}
\hline Composites & $\begin{array}{c}\text { Trial } \\
\mathbf{1}\end{array}$ & $\begin{array}{c}\text { Trial } \\
\mathbf{2}\end{array}$ & $\begin{array}{c}\text { Trial } \\
\mathbf{3}\end{array}$ & Avg \\
\hline Plain & 50 & 51 & 53 & 51 \\
\hline 10\% Carbon & 55 & 60 & 51 & 55 \\
\hline $20 \%$ Carbon & 65 & 72 & 67 & 68 \\
\hline $30 \%$ Carbon & 82 & 81 & $\mathbf{7 9}$ & 80 \\
\hline
\end{tabular}

The higher hardness is exhibited by the $30 \mathrm{wt} \%$ carbon filled composite compared to other micro composites. The table shows that for a $30 \mathrm{wt} \%$ increase in carbon content there is $45 \%$ increase in hardness. The increase in carbon content results in an increase in brittleness of the composite.

\subsubsection{Compression Test}

It can be noticed that for the plain E-glass/Epoxy material the compressive strength value across the fiber is $23.33 \mathrm{~N} / \mathrm{mm}^{2}$ and along the fiber is $27.7 \mathrm{~N} / \mathrm{mm}^{2}$. With the addition of carbon as filler material it is seen that the compressive strength values are increasing. A maximum is seen at $30 \%$ carbon filled material. For $30 \%$ carbon filled material the compressive strength across the fiber is $25.667 \mathrm{~N} / \mathrm{mm}^{2}$ and along the fiber is $33.33 \mathrm{~N} / \mathrm{mm}^{2}$.

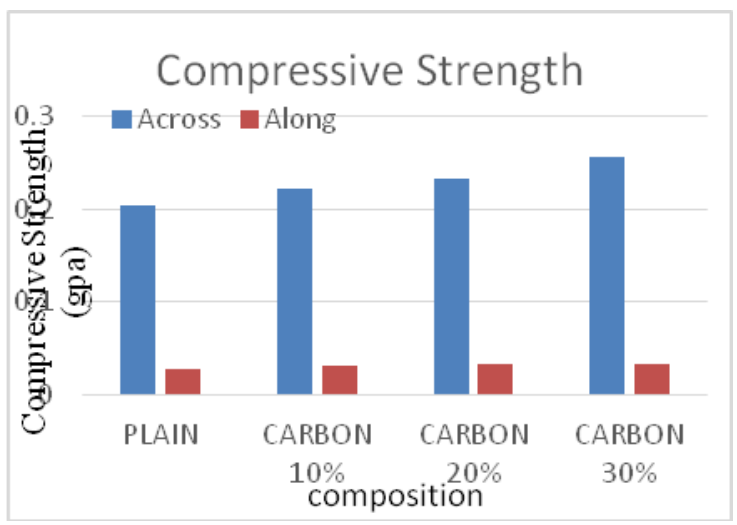

Fig. 5 Compressive strength Vs. Composition 
International Journal of Engineering Applied Sciences and Technology, 2020

Vol. 5, Issue 4, ISSN No. 2455-2143, Pages 415-419

Published Online August 2020 in IJEAST (http://www.ijeast.com)

\subsubsection{Wear Test}

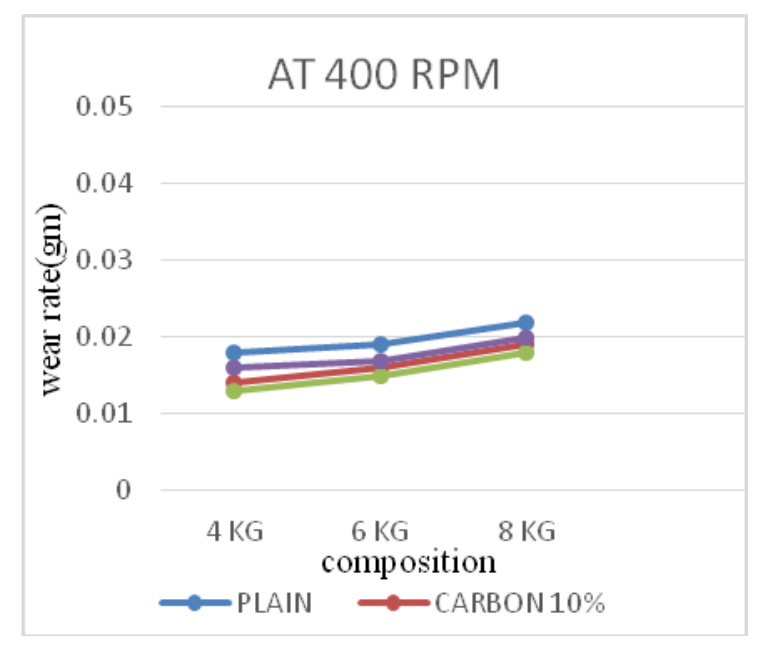

Figs 6 wear loss at 400rpm

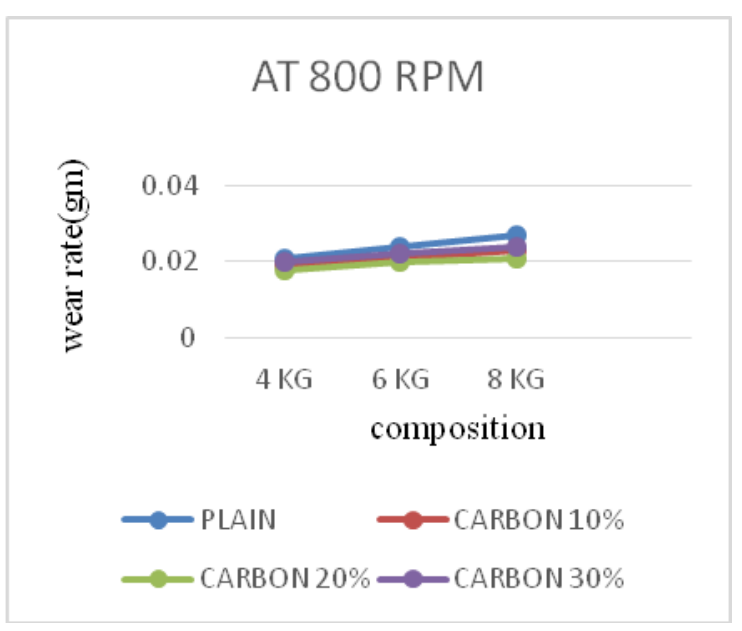

Figs 7 wear loss at 800rpm

The experimental results reveal that weight loss for all samples increases when there is increase in the normal load applied as we can see in the above fig. The carbon filled Eglass/Epoxy [7] (2006) composite exhibited considerably lower wear volume loss than that of plain E-glass/Epoxy composite. Moreover, the weight loss of the composites filled with natural fillers depends upon some basic characteristics such as, shape of the filler,[8] (2011) size of the filler, and hardness and thermal conductivity of the filler materials.

\section{CONCLUSION}

As seen in the investigation of Epoxy-Carbon composite material (without E-glass reinforcement) 30wt\% filled carbon has a compressive strength up to $99 \mathrm{~N} / \mathrm{mm}^{2}$ when compared to the other composite materials and $30 \mathrm{wt} \%$ carbon filled composite exhibit very less material wear loss at a load of 40 $\mathrm{N}$ and $80 \mathrm{~N}$ with 400 and $1200 \mathrm{rpm}$ speed respectively.

For Epoxy-Carbon composite material (with E-glass reinforcement). Compared with plain $\mathrm{E}$ glass epoxy composite, the hardness of carbon filled e glass epoxy improves, also the compressive strength across the fiber has a good improvement than along the fiber where a slight increment is observed. The higher percentage $(30 \mathrm{wt} \%)$ of carbon content in e glass epoxy composite results to higher compressive strength, hardness and $20 \mathrm{wt} \%$ carbon content has better wear resistance.

\section{ACKWOLDGEMENT}

I gratefully acknowledge the support and guidance of Prof. Dr. Basava T, Head R\&D/IEDC, Department of Mechanical Engineering, SDMIT, UJIRE. And Mr. Naveen C R, Department of Mechanical Engineering, Srinivas Institute of Technology, Mangalore, and the Faculties of Srinivas Institute of Technology, Mangalore.

\section{REFERENCE}

1. Rothon R N, Jancar J, (1999), "Mineral fillers in thermoplastics filler manufacture and characterization" Advance Polymer Science, Vol 139, Issue 67.

2. K.Devendra, T. Rangaswamy (2012), "Evaluation of Thermal Properties of E-Glass/ Epoxy Composites Filled By Different Filler Materials" International Journal Of Computational Engineering Research (ijceronline.com) Vol. 2 Issue.5, pp 1708-1714.

3. K.Devendra, T. Rangaswamy (2013) "Thermal conductivity and thermal expansion coefficient of gfrp composite laminates with fillers". ISSN: 2320-2491, Vol 2, No 5, pp. 39-44.

4. Sudharshanrao, Y S Varadarajan and N Rajendra, (2009), "Investigation of the abrasive wear behaviour of graphite filed carbon fabric reinforcement epoxy composite" IJMET, Vol 267, Iss 9-10, pp. 1405-1414.

5. S R Rama, G K pavithra, S K Rai (2013) “ study on mechanical \& fractographic behavior of poly carbonate toughened Epoxy- granite particles hybrid composites" https://doi.org/10.1080/03602559.2013.779707, pp. 11221126.

6. Basava T, A N Hari rao (2011) “ Development of graphite particles filled epoxy resin composite material and its erosive wear behaviour" IJMMS, Vol 1, No 2, pp. 28-30.

7. Suresha B, Chandramohan (2006), "Mechanical and tribological properties of glass epoxy composites with and without graphite particulate filler", Journal of applied polymer science, https://doi.org/10.1002/app.25413

8. N Mohan, S Natarajan \& P Kumareshbabu (2011) "sliding wear behaviour of graphite filled glass epoxy composites at 
elevated temperatures", polymer plastic technology \& engineering, Vol 50, Issue 3, pp 251-259

9. Beyerlein I. J, Zhu Y. T and Mahesh S (2001), "On the influence of fiber shape in bone shaped short-fiber composites", Composite science and technology, Elsevier, Vol 61, Iss 10, pp. 1341-1357.

10. Kari S, Berger H and Gabbert U (2007), "Numerical evaluation of effective, material properties of randomly distributed short cylindrical fibre composites", Computational materials science, Elsevier, vol 39, Issue 1, pp. 198-204.

11. Hine P. J, Davidson N. D and Ward I. M (1995) "Measuring the fiber orientation and modeling the elastic properties of injection molded long-fiber reinforced nylon", Composite science and technology, Elsevier, Vol 53, Issue 2, pp. 125-131.

12.Fu S.Y, Hu X.Y and Chee Y (1999), "The flexural modulus of misaligned short fiber reinforced polymers", Composite science and technology, Elsevier, Vol 59, Issue 10, 15331542.

13.Corum J. M, Battiste R. L, Ruggles M. B and Ren W (2001) "Durability based design criteria for a chopped glass fiber automotive structural composite", composite science and technology, Elsevier, Vol 61, Issue 8, pp. 1083-1095.

14.Zhang S.Y, Soden P. D and Soden P. M (1986), "Interlaminar shear fracture of chopped strand mat glass fibre reinforced polyester laminates", composite science and technology, Elsevier, Vol 17, Issue 2, pp. 100-110.

15.Prisco U, Caprino G and Giorleo G, (2004) "Influence of the flexibiliser content on the monotonic and fatigue behaviour of a polyester resin for composites" Compos Part A, Vol 35, Issue 9, pp. 1081-1089.

16.Sivakumar, Mr. Anjithkumar, Ms. asikumar.S, Prabhu.D, Sabarish.C, Sengottaiyan.P (2016), "Mechanical properties and sem analysis of glass/nylon/jute reinforced epoxy hybrid composites", IJMET, ISSN: 0976-6340, Vol 7, Issue 2, pp. 196-207.

17. Lokesh V (2017) "Study of mechanical and tribological properties of hybrid composite material E-glass/epoxy with carbon powder" IJESM, ISSN 2277-5578, pp. 73-80. 